\title{
The Golden Age of China-Taiwan Relations: The Explanation and Its Future
}

\section{Daniel Tantra Wiratama}

Mahasiswa Jurusan Hubungan Internasional, Fakultas IImu Sosial dan IImu Politik, Universitas Katolik Parahyangan

\begin{abstract}
The past eight years since 2008 under the leadership of Ma Ying-jeou, the relations between China and Taiwan have been experiencing the golden age. By cooperating in many sectors, like economic partnership; social interactions; tourism and some political dialogues, both countries have been building a good relationship between them. Looking back to the past, China and Taiwan have a long series of conflicts, which ended in the Chinese Civil War 1949 with the victory of the Chinese Communist party which has now become the People's Republic of China. Meanwhile, its opposing democratic party has now become the Republic of China (Taiwan). Since then, China and Taiwan's relations have been on a standstill Ma Yingjeou rose to power as the president of Taiwan. By using the concept of Economic Interdependence and Conflict in World Politics by Mark J.C. Crescenzi, this paper aims to explain how the golden age of China-Taiwan relations have been going on in the past eight years up until now, as well as the future of the relations itself under the new president of Taiwan, Tsai Ing-we. This paper has the following research question: how has the good relation between China and Taiwan been built since 2008, considering their previously severed relations in the past?

Keywords: China-Taiwan Relations; Chinese Civil War; Relations; Economic Interdependence and Conflict in World Politics.
\end{abstract}

\section{The Golden Age of China-Taiwan Relations: The Explanation and Its Future}

There are so many reasons behind the split of People's Republic of China and Republic of China (Taiwan). Started from Chinese Civil War in the 1949, now they have divided into two different entities. Even both of them have a long series of conflicts, since 2008, both China and Taiwan has a good relationship which leads to interdependence. By cooperating in many sectors like economic partnership, political dialogue, tourism and other cooperation, China and Taiwan have made a close ties each other.

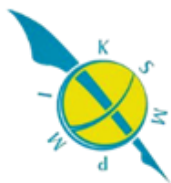


Since 2008, the good relationship between China and Taiwan has been the golden age of their relation up until 2016. Under the presidency of Ma Ying-Jeou, Taiwan has built a trust with China, despite the 1992 consensus which underlying that Taiwan belongs to China.

"Referred to as the 1992 Consensus, it states that there is only one China, but with differing interpretations, allowing both Beijing and Taipei to agree that Taiwan belongs to China, while the two still disagree on which is China's legitimate governing body. The tacit agreement underlying the 1992 Consensus is that Taiwan will not seek independence. " 1

The interdependence between China and Taiwan has made a good example for the relations among entities. Even both has a long series of conflict, they could build a trust and also a cooperation which beneficial for them. In 2016, the new president of Taiwan, Tsai Ing-we, who doesn't agree with the 1992 Consensus would has an impact for the golden age of China and Taiwan relation. She (Tsai Ing-we) doesn't like the "1992 Consensus," the precondition that $\mathrm{Ma}$ and China set before hatching talks. ${ }^{2}$ This paper would farther discuss about how how has the good relation between China and Taiwan been built since 2008, considering their previously severed relations in the past.

\section{Chinese Civil War 1949 and the Establishment of Republic of China (RoC)}

The defeat of Japan in the World War II was the key moment for the establishment of Republic of China (Roc). But Japan's defeat in World War

\footnotetext{
${ }^{1}$ Eleanor Albert, "China-Taiwan Relations," Council on Foreign Relations, accessed on November $24^{\text {th }} 2016$, http://www.cfr.org/china/china-taiwan-relations/p9223.

2 Ralph Jennings, "China-Taiwan Relations To Take A Holiday Under New President," Forbes, accessed on November $24^{\text {th }} 2016$, http://www.forbes.com/sites/ralphjennings/2016/05/16/china-taiwan-relations-to-takeholiday-under-new-president/\#59f18e7f52af.
} 
Two led to the US and Britain agreeing that Taiwan should be handed over to their ally, Chiang Kai-shek's Republic of China government, which was then in control of most of China. ${ }^{3}$ On October 1, 1949, Chinese Communist leader Mao Zedong declared the creation of the People's Republic of China (PRC). ${ }^{4}$ The rivalry between Chiang and Mao led to the Chinese revolution in 1949. The clash between democratic and communist parties and communist as the victory, China mainland became the People's Republic of China (PRC).

"In October of 1949, after a string of military victories, Mao Zedong proclaimed the establishment of the PRC; Chiang and his forces fled to Taiwan to regroup and plan for their efforts to retake the mainland." 5

For more than twenty years after the revolution of 1949, PRC and RoC had a hostile and angry rhetoric relation. There are no contacts, limited trade and no diplomatic ties between the two entities.

"Chiang and the remnants of his Kuomintang (KMT) government fled to Taiwan in 1949. This group, referred to as Mainland Chinese and then making up $1.5 \mathrm{~m}$ people, dominated Taiwan's politics for many years, even though they only account for $14 \%$ of the population." 6

After that, Taiwan under Chiang was running his government under the nationalist forces. These two entities were different with their own ideologies and government system. China put forward a formula, known as "one country, two systems", under which Taiwan would be given significant autonomy if it accepted Chinese reunification. ${ }^{7}$ The international recognitions were also different, regarding to the issue of ideology in the moment of Cold War.

\footnotetext{
3 “What's behind the China-Taiwan divide?," BBC, accessed on November $24^{\text {th }} 2016$, http://www.bbc.com/news/world-asia-34729538.

4 "The Chinese Revolution of 1949," Office of The Historian, accessed on November $24^{\text {th }}$ 2016, https://history.state.gov/milestones/1945-1952/chinese-rev.

${ }^{5}$ Ibid.

6 "What's behind the China-Taiwan divide?" BBC, accessed on November 24th 2016, http://www.bbc.com/news/world-asia-34729538.

${ }^{7}$ Ibid.
} 
"the UN switched diplomatic recognition to Beijing and the ROC government was forced out. Since then the number of countries that recognize the ROC government diplomatically has fallen to about $20 .{ }^{8}$ "

\section{The Golden Age of China-Taiwan Relations}

Taiwan under the leadership of Ma Ying-jeou since 2008 has seemingly been a golden age for these two entities. Taipei and Beijing have finalized two dozen economic agreements, cross-strait travel and tourism have reached new heights, and collaboration between working-level government officials has become standard operating procedure. ${ }^{9}$ The golden age itself means that both China and Taiwan have been cooperated in many sectors, as a trading partner.

"Bilateral trade between China and Taiwan in 2014 reached \$198.31 billion, up from $\$ 8$ billion in 1991 (PDF). China is Taiwan's largest trading partner, accounting for almost 30 percent of the island's total trade (including the mainland, Hong Kong, and Macao), according to Taiwan's bureau of foreign trade. ${ }^{10}$ "

There was a need from Taiwan to China as a trading partner. Even politically Taiwan has not recognized as a sovereign state, on the economic sector Taiwan has become an independent entity compared to other countries. Likewise, Taiwan ranks seventh among China's top ten trading partners. ${ }^{11}$ There is a mutual need among them.
"Over ninety-three thousand Taiwanese businesses have invested in the mainland since 1988. Reciprocal mainland investment by Taiwanese firms is on the rise but at a slower rate, totaling $\$ 34.5$ billion between 2008 and mid-2015. China and Taiwan have also agreed to allow banks, insurers, and other financial service providers to work in both markets. In 2015, the number of direct flights between China and

\footnotetext{
8 Ibid.

${ }^{9}$ Shelley Rigger, "The End of a Golden Age in China-Taiwan Relations?," Carnegie-Tsinghua Center for Global Policy, http://carnegietsinghua.org/2016/06/24/end-of-golden-age-inchina-taiwan-relations/i2h2, accessed on November 25 2016.

${ }^{10}$ Eleanor Albert, "China-Taiwan Relations," Council on Foreign Relations, accessed on November 25th 2016, http://www.cfr.org/china/china-taiwan-relations/p9223. ${ }^{11}$ Ibid.
} 
Taiwan hit 890 per week, up from 270 in 2009. More than 9.4 million people traveled across the strait in 2014, and in September 2015

Taiwan upped its daily quota of mainland visitors from four thousand to five thousand. ${ }^{12}$ ",

Meanwhile, both of them are not only active in trading activities, but also in signing agreement to enhance the partnership among them. President Ma (2008-2016) signed more than twenty pacts with the PRC, including the 2010 Economic Cooperation Framework Agreement (ECFA) (PDF), a crossstrait agreement to lift barriers to trade. ${ }^{13}$

\footnotetext{
12 Ibid.
}

13 Ibid. 


\section{Taiwan-China trade}

Since 2008, Taiwan's China-friendly President Ma Ying-jeou has signed a series of landmark trade and economic agreements with Beijing, but both sides have showed little desire for political dialogues.

— Taiwan's exports to mainland China — Taiwan's imports from mainland China

$\$ 10$ billion

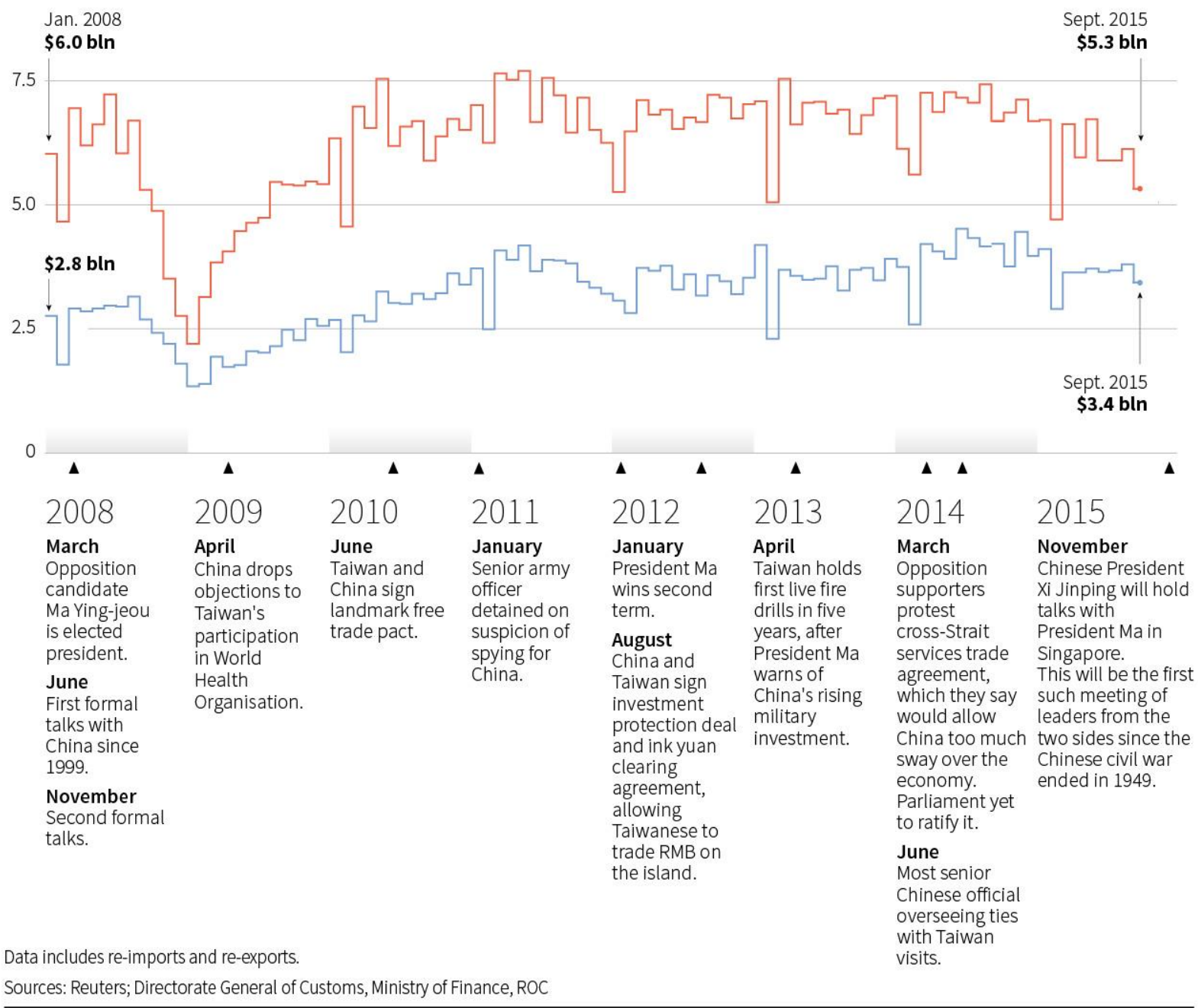

Staff, C. Inton, 04/11/2015

By looking at this cooperation, we can see that these two entities have conducted a comprehensive partnership and agreement. A mutual benefits and

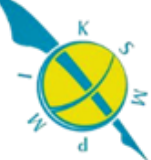


ISSN 0216-5031

understandings have made a key role for their relations. The relations are also made a ties which made them a relation that so-called interdependence, the symmetric cooperation.

\title{
Theoretical Framework - Economic Interdependence and Conflict in World Politics by Mark J.C. Crescenzi
}

In the liberalist point of view, economic interdependence was believed could reduce conflict or tension among states. Mark J.C. Crescenzi said that there are three mechanism states use to extract such bargaining power from their economic relationship. ${ }^{14}$

"First, I define economic interdependence as a function of the potential exit costs states incur by breaking economic ties. These exit costs set apart interdependence from other qualities of interstate economic relations. Whereas economic interaction can be thought of simply as the transaction of goods or services between states, interdependence carries with it a connotation of constraint and a tangled web of commitments that are costly to break. ${ }^{15}$ "

When two entities have an economic interdependence, the exit cost must be a consideration for them to break apart from it. The close ties and the commitments are something to be lasted, because the economic ties could influenced their other economic activities. After that, economic interdependence also could reduce political conflict which leads to peace.

\begin{abstract}
"One perspective argues that economic exchange has a negative impact on political conflict, leading to a more peaceful world. A contradictory body of research asserts that the relationship is positive, with economic exchange generating more conflictual behavior between states. Finally, a third argument posits that economic exchange is not sufficiently important to states to have any impact upon their decisions to engage in or avoid political conflict. ${ }^{16 ،}$
\end{abstract}

\footnotetext{
${ }^{14}$ Based on Mark J.C. Crescenzi's three mechanisms, this paper only needs the first mechanism.

${ }^{15}$ Mark J.C. Crescenzi, Economic Interdependence and Conflict in World Politics(Chapel Hill: University of North Carolina, 2002), p.8.

${ }^{16}$ Ibid, p.16.
} 
Looking to the first perspective, economic exchange could reduce political conflict, rather than generating more conflictual behavior. Economic markets, if left alone by states to evolve and develop, will gradually interconnect states by economic means such as trade, thereby reducing the need for political boundaries and conflicts. Economic exchange will lead to security interests being replaced by economic interests. ${ }^{17}$ The security interests and economic interests are both national interest, but one of them could be a priority for a state in running its government.

William Domke effectively captures the hopes of many scholars and policy-makers when he argues that the most potent challenge to the primacy of security is the pursuit of prosperity" (1988: 29).

"Domke argues that the increase in wealth within each country resulting from trade generates a snowballing effect on political conflict. Those who benefit from this increase in wealth put pressure upon their governments to seek peaceful means of resolving disputes with other countries. ${ }^{18}$

\section{Analysis - The Golden Age of China-Taiwan Relations}

To analyze farther about the golden age of China-Taiwan relations since 2008 and to give an explanation about how their relations goes well after their long-series of conflict, Mark J.C. Crescenzi's concept about Economic Interdependence and World Conflict is a perfect concept for a prominent application of economic interdependence which could reduce conflict(s). Referring back to the case of China-Taiwan relations, after the Chinese Civil War 1949, both entities have frozen relations. Since 2008 under the leadership

\footnotetext{
17 Ibid, p.17.

${ }^{18} \mathrm{Ibid}, \mathrm{p} .18$.
} 
of Ma Ying-jeou, Taiwan has a close ties, especially in economic sector with China.

Looking to the cooperation and agreements, both entities couldn't break their partnership because of the exit costs in which mentioned before in the theoretical framework. The economic interdependence is a close ties among them and has mutual benefits for them. The commitment would last along with the relations among them and the exit costs would also be the binding commitment.

On the other hand, the golden age of China-Taiwan relations are also reducing conflict among them. The economic interests between China and Taiwan could be the higher priority rather than security interests, especially in Taiwan Strait. The bilateral trade among trade which getting higher gradually since 2008 and make them as one of the largest trading partner as mentioned above. There is an interconnection between China and Taiwan, and these connections were hatched from the economic cooperation and evidently reduce conflict and tension among them.

The disputes and conflicts between China and Taiwan are reduced due to the comprehensive economic partnership and agreement from them. The 'snowballing effect' concept from Domke could explain why do the tensions are reduced. The pressure for their government to seek peaceful means caused by the economic partnership which related to exit costs and the pursuit of prosperity and resulted in political engagement, and makes it to the so-called golden age of China-Taiwan relations.

\section{The Future of China-Taiwan Relations}

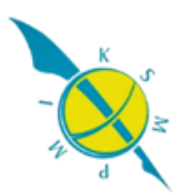


Since the inauguration of Taiwan's new president, Tsai Ing-wen from Democratic Progressive Party in Taiwan, the golden age of China-Taiwan relations left a big question for their future relations. Tsai Ing-wen, which took the office in the May $20^{\text {th }}$, is questioned for their policy towards China. Regarding to the 1992 consensus, Tsai Ing-wen said that she might not acknowledge it in her leadership for the next four or eight years. Instead, the most novel element in the speech was a reference that reinforces Taiwan's status as a Chinese entity. ${ }^{19}$

"Tsai said that the 1992 meetings "arrived at various joint
acknowledgements and understandings" and that she "respect[s] this
historical fact." Respecting a historical fact is as close as one can get
to accepting it without actually doing so; citing "joint
acknowledgements and understandings" is as close as one can get to
the idea of consensus without actually using the word itself.

The next question would be about the communication, partnership and the tensions between them. The good political dialogue and partnership under the leadership of Ma could be maintained under Tsai's leadership if both entities could maintain their interdependence. The tension in Taiwan Strait is also a big concern for China and Taiwan, regarding the acknowledgment of Taiwan as a sovereign state and running for its independence. "At present, relations across the Taiwan Strait are extremely sensitive and complex, and uncertainly about the future has increased," Zhang told Hsia, according to China's official Xinhua news agency. ${ }^{21}$

\footnotetext{
${ }^{19}$ Shelley Rigger, "The End of a Golden Age in China-Taiwan Relations?," Carnegie-Tsinghua Center for Global Policy, accessed on November 25th 2016, http://carnegietsinghua.org/2016/06/24/end-of-golden-age-in-china-taiwanrelations/j2h2.

${ }^{20}$ Ibid.

21 "It's complicated, China says of relationship with Taiwan," Reuters, accessed on November 25th 2016, http://www.reuters.com/article/us-china-taiwan-idUSKCNOVEOMP.
} 


\section{CONCLUSION}

To conclude this paper, China and Taiwan have a long-series of conflict since the Chinese Civil War 1949. The civil war that occurred a revolution, made a separation between People's Republic of China (PRC) and Republic of China (RoC). As the victory of communist party, PRC took the China mainland and RoC move to the new land, the so-called Taiwan. After this conflict, China and Taiwan have frozen relations.

After the 1992 Consensus between China and Taiwan, there is only one China, and Taiwan is referred to China. Since this consensus, China and Taiwan started to have a dialogue until the golden age of China-Taiwan relations since 2008 under the leadership of Ma Ying-jeou, Taiwan-elect president. In this golden age, China and Taiwan have a comprehensive partnership and agreement in economic sector, and also mutual benefits and understanding for them.

Mark J.C. Crescenzi's concept about economic interdependence and world conflict is a perfect concept to explain how China and Taiwan could have good relations, despite the long-series of conflict in the past. First, economic interdependence is a symmetric cooperation between two entities. There are exit costs which could be a consideration for them to break their relations that usually happen because of political tensions.

Meanwhile, economic exchange like trading of goods and services could reduce conflict. Economic interests could be a higher priority for a state, rather than security interests. The interconnection between them in economic ties could bind their relations, and gradually develop to make interdependence. Lastly, the 'snowballing effect' concept from William Domke is a concept in which a government could be pressured by economic interest to maintain a

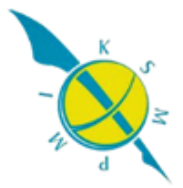


good relations to other entity, to ensure the increasing wealthy and resolving disputes to maintain a good relationship.

By understanding this concept, it is clear how China and Taiwan could have a golden age of their relations. Economic interdependence could lead to peace and maintaining a good partnership. And finally, the future of golden age of China-Taiwan relations could be a big question, under Taiwan's new president, Tsai Ing-wen who reinforces Taiwan's status as Chinese entity in her political campaign until she took the office in the May $20^{\text {th }}$. Could it be maintained

\section{BIBLIOGRAPHY}

\section{Article}

Crescenzi, Mark J.C.. Economic Interdependence and Conflict in World Politics. Chapel Hill: University of North Carolina. 2002.

\section{Internet}

Albert, Eleanor. "China-Taiwan Relations." Council on Foreign Relations. accessed on May 18 ${ }^{\text {th }}$ 2016. http://www.cfr.org/china/china-taiwan-relations/p9223.

"It's complicated, China says of relationship with Taiwan." Reuters. February $5^{\text {th }} 2016$. http://www.reuters.com/article/us-china-taiwan-idUSKCNOVEOMP.

Jennings, Ralph. "China-Taiwan Relations To Take A Holiday Under New President." Forbes. May $16^{\text {th }}$ 2016. http://www.forbes.com/sites/ralphjennings/2016/05/16/chinataiwan-relations-to-take-holiday-under-new-president/\#59f18e7f52af.

"The Chinese Revolution of 1949." Office of The Historian. https://history.state.gov/milestones/1945-1952/chinese-rev.

"What's behind the China-Taiwan divide?." BBC. November 6 $6^{\text {th }} 2015$. http://www.bbc.com/news/world-asia-34729538.

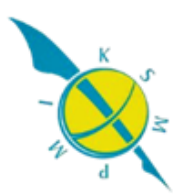

